\title{
First geochemical and geochronological characterization of Late Cretaceous mesosilicic magmatism in Gastre, Northern Patagonia, and its tectonic relation to other coeval volcanic rocks in the region
}

\author{
CLAUDIA ZAFFARANA* $+\dagger$, SILVIA LAGORIO§, DARÍO ORTS*!, \\ ALICIA BUSTEROS, DIEGO SILVA NIETO $\S$, RAÚL GIACOSA*§, VÍCTOR RUIZ

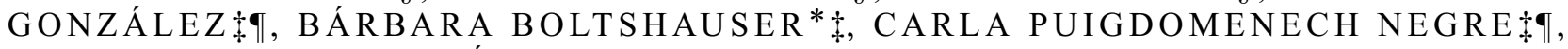 \\ RUBÉN SOMOZATđ \& MIGUEL HALLER \#I \\ *Universidad Nacional de Río Negro, Sede Alto Valle-Valle Medio. Av. Julio A. Roca \\ 1242 General Roca (8332), Pcia. de Río Negro, Argentina \\ †Consejo Nacional de Investigaciones Científicas y Técnicas (CONICET), \\ Godoy Cruz 2290, C1425FQB, Buenos Aires, Argentina \\ $\S$ Servicio Geológico Minero Argentino (SEGEMAR), Av. General Paz 5445, B1650WAB, Buenos Aires, Argentina \\ qDepartamento de Geología de la FCEyN, Universidad de Buenos Aires, Intendente Güiraldes 2160, \\ Ciudad Universitaria, C1428EGA, Buenos Aires, Argentina \\ ||Universidad Nacional de la Patagonia San Juan Bosco, Puerto Madryn, Argentina
}

(Received 14 December 2017; accepted 1 May 2018)

\begin{abstract}
This work characterizes Late Cretaceous calc-alkaline volcanic rocks in Gastre, Northern Patagonia, Argentina. These newly found porphyritic rocks bear an ${ }^{40} \mathrm{Ar}-{ }^{39} \mathrm{Ar}$ amphibole age of 74-76 Ma, a subduction-type geochemical signature and a deep, garnet-bearing source. Extruded in a stage of low magmatic activity in the Northern Patagonian Andes $\left(\sim 41-44^{\circ} \mathrm{S}\right)$, they could represent an eastward migration of the Late Cretaceous magmatic arc that was associated with a regional compressive deformational stage in the South American margin.
\end{abstract}

Keywords: subduction magmatism, slab shallowing, compressive deformation, Tres Picos Prieto, Chile Ridge

\section{Introduction}

This work characterizes a previously unknown outcrop of Late Cretaceous porphyritic rocks near the area of Gastre in Northern Argentine Patagonia. It is based on petrographic, geochronological and geochemical data of representative samples located at latitude $42^{\circ} 03^{\prime} 29.9^{\prime \prime} \mathrm{S}$ and longitude $69^{\circ} 09^{\prime} 28.4^{\prime \prime} \mathrm{W}$ (samples G4-230 and G4-232) and at latitude $42^{\circ} 03^{\prime} 35.01^{\prime \prime} \mathrm{S}$ and longitude $69^{\circ} 09^{\prime} 27.965^{\prime \prime} \mathrm{W}$ (sample T3, Fig. 1). These rocks were previously included within the Early-Middle Jurassic calc-alkaline volcanic belt known as the Lonco Trapial Formation (Page \& Page, 1993; Zaffarana \& Somoza, 2012; Bouhier et al. 2017).

The porphyritic rocks from Gastre were dated to between $\sim 74$ and $76 \mathrm{Ma}$ (Table 1), when a gap or waning in activity was registered in the Northern Patagonian Batholith (this period ranged from $76 \mathrm{Ma}$ to $c$. $40 \mathrm{Ma}$; Pankhurst

†Author for correspondence: czaffarana@unrn.edu.ar et al. 1999; Suárez et al. 2010; Echaurren et al. 2017). The Patagonian Batholith is a main feature of the Andean cordillera; it extends between $40^{\circ}$ and $53^{\circ} \mathrm{S}$, and its episodically emplaced plutons represent subduction processes that took place in the continental margin from Early Jurassic to Pleistocene times (Pankhurst et al. 1999; Rolando et al. 2002; Castro et al. 2011).

The age of the porphyritic rocks from Gastre coincides with the age of the upper section of the Tres Picos Prieto Formation, a basaltic sequence located at $44^{\circ} \mathrm{S}$, near the locality of José de San Martín (Fig. 1; Di Tommaso, unpub. Trabajo Final de Licenciatura, Univ. de Buenos Aires, 1978; Franchi \& Page, 1980). Further southwest, in the Coihaique Alto region in Chile at $45^{\circ} \mathrm{S}$, the volcanic rocks from the Casa de Piedra Volcanic Complex and the El Toro Formation also bear a similar Late Cretaceous age (Fig. 1; Demant, Suárez \& De La Cruz, 2007). The porphyritic rocks from Gastre bear a geochemical signature typical of subductionderived magmas, which is also found in the Tres Picos Prieto basalts (especially in the upper section; Zaffarana, Lagorio \& Somoza, 2012) and in the volcanic rocks from the Coihaique Alto region (Demant, Suárez \& De La Cruz, 2007). Therefore, it is put forth that the porphyritic rocks from Gastre could represent an eastward shift in the position of the magmatic arc at $42^{\circ} \mathrm{S}$, as they were erupted $c .270 \mathrm{~km}$ away from the axis of the magmatic arc (represented by the outcrops of the Northern Patagonian Batholith; Fig. 1). This eastward migration of the magmatic arc was probably the result of a slab-shallowing process; slab shallowing was also argued to explain the Late Cretaceous compressive deformation observed in the Gastre area (Echaurren et al. 2016, 2017; Savignano et al. 2016). Nevertheless, it should be noted that during Late Cretaceous times the magmatic arc regained its westward position further south at the latitude of the Coihaique Alto region (Fig. 1; Demant, Suárez \& De La Cruz, 2007). 


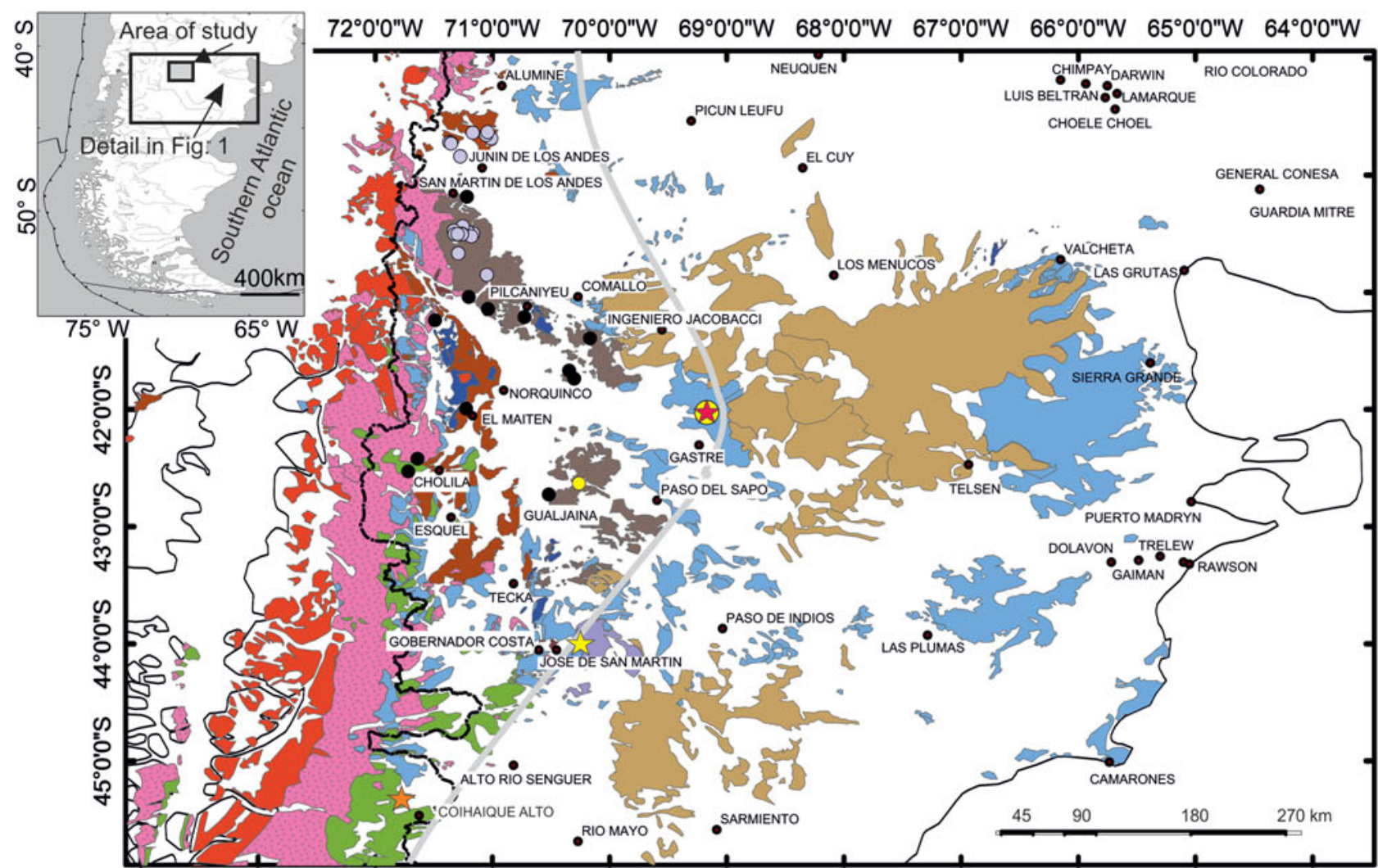

Magmatic rocks in the axis of the Northern Patagonian Andes and in the retroarc

Within-plate magmatic series

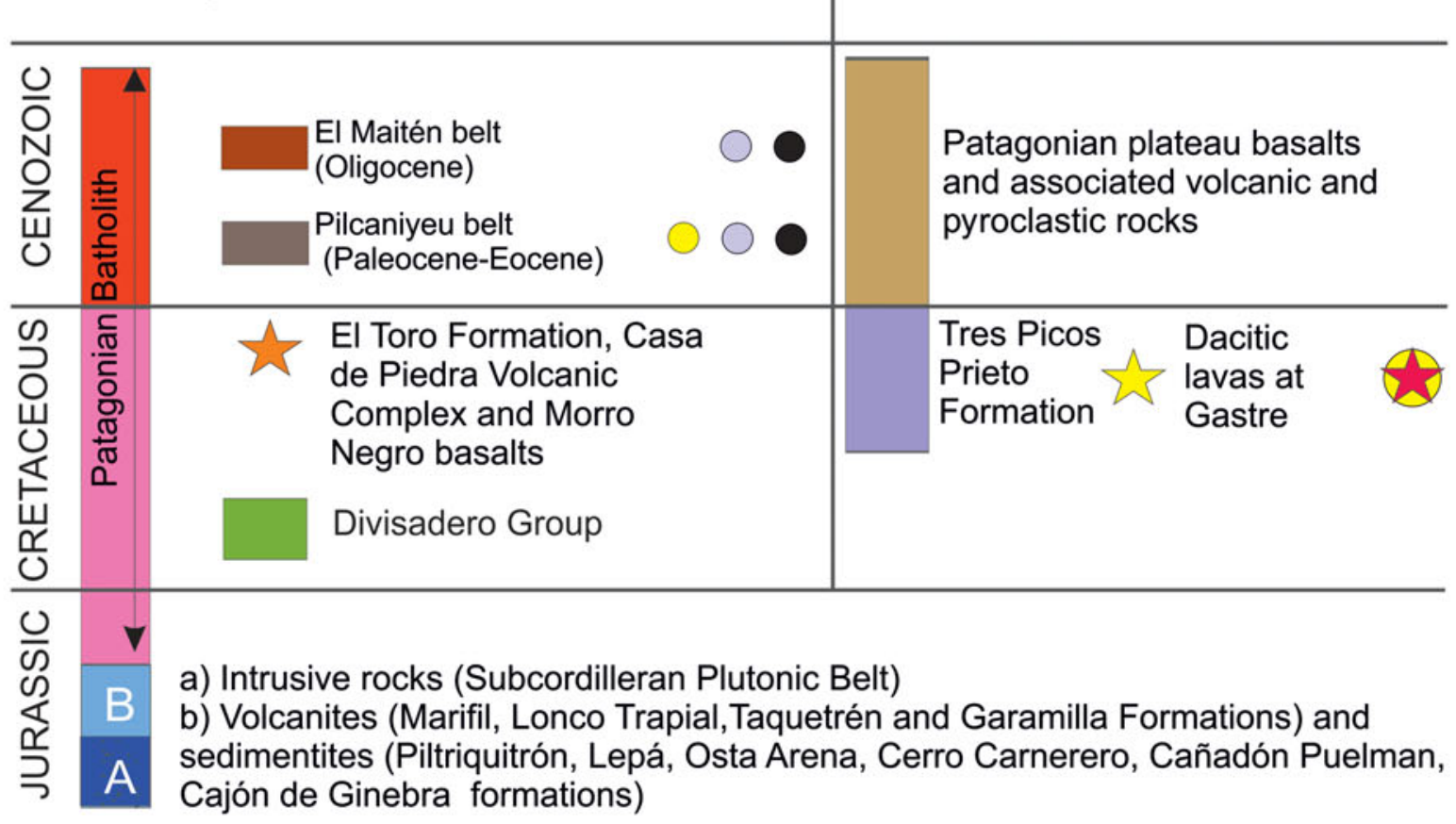

Sampling code

- Rapela et al. (1988)

lannelli et al. (2017)
Aragón et al. (2011)

Zaffarana et al. (2012)
Demant et al. (2007)

This work

\section{Eastern border of the Late Cretaceous-Palaeogene magmatic front}

Figure 1. (Colour online) Regional map showing the location of the Late Cretaceous outcrops of Gastre in the context of the Jurassic to Cenozoic main magmatic and sedimentary series. 
Table 1. Summary of geochronological data (errors given at $1 \sigma$ level)

\begin{tabular}{llccc}
\hline Sample & Material & Total gas age (Ma) & Plateau age (Ma) & Isochron age (Ma) \\
\hline T3 & Amphibole & $87.72 \pm 0.33$ & $76.13 \pm 0.44$ & $68.60 \pm 0.55($ steps $5-13)$ \\
G4-230 & Amphibole & $75.2 \pm 1.3$ & $74.3 \pm 1.4$ & $75.2 \pm 1.3($ all steps) \\
\hline
\end{tabular}
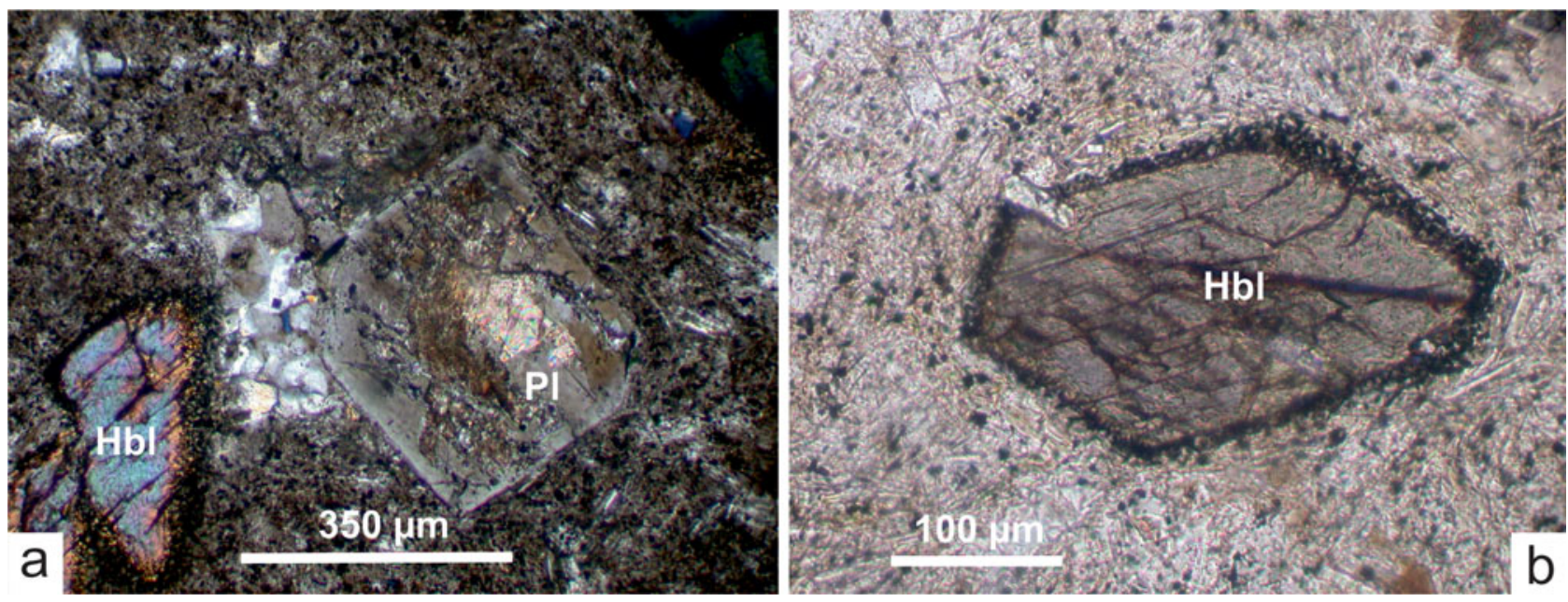

Figure 2. (Colour online) Petrography of the dacitic lavas at Gastre. (a) Hornblende and plagioclase phenocrysts. Photograph taken under crossed polars. (b) Detail of amphibole phenocryst with intense resorption border. Photograph taken under plane-polarized light. Mineral abbreviations after Whitney \& Evans (2010). Hbl - hornblende; Pl - plagioclase.

\section{Outcrop characterization and petrography}

The porphyritic rocks from Gastre overlie the Lower to Middle Jurassic andesitic lavas and breccias of the Lonco Trapial Formation (Page \& Page, 1993; Zaffarana \& Somoza, 2012), which they notably resemble. Xenoliths of the Lonco Trapial lavas are found enclosed in these porphyritic rocks. They are composed of $30 \%$ phenocrysts, which consist of hornblende $(20 \%)$ and plagioclase $(10 \%)$, and which are immersed in a pilotaxitic groundmass (Fig. 2). Hornblende phenocrysts are green pleochroic with euhedral prismatic sections up to $5 \mathrm{~mm}$ in length (Fig. 2). They are fresh and frequently twinned with occasional zonation and inclusions of apatite. They show resorption borders with a formation of small grains of opaque minerals in the rims (Fig. 2). Plagioclase laths $\left(\mathrm{An}_{50}\right)$ can reach up to $1.7 \mathrm{~mm}$ in length; they are subhedral with frequent polysynthetic twinning and zonation, and also with a moderate alteration to clays, sericite, analcime veins and carbonatic patches (Fig. 2a). The angular interstices between the plagioclase grains are occupied by hornblende, opaque minerals, quartz and interstitial glass. The glass is replaced by alkaline feldspar and zeolites. Quartz is of secondary origin and is associated with alteration of carbonates and K-feldspar.

\section{Analytical methods}

Samples were selected based on their freshness, and amphibole single grain analyses were carried out on grains of the order of 251 and $178 \mu \mathrm{m}$ in size (60-80 mesh grain size). The amphibole separates were sent to two different laboratories for ${ }^{40} \mathrm{Ar}-{ }^{39} \mathrm{Ar}$ age determination by furnace stepheating on single grains. Sample T3 was analysed at the Arizona Noble Gases Laboratory of the University of Arizona (USA), and sample G4-230 was irradiated at the Activation Laboratories Ltd (Actlabs), Ancaster, Ontario, Canada.

Whole-rock geochemical data were obtained at Actlabs, Canada (sample G4-230), at the Acme Analytical Labor- atories (Acmelabs), Vancouver, Canada (sample T3) and at the Instituto de Tecnología Minera (INTEMIN; Servicio Geológico Minero Argentino), Argentina (sample G4232). At Actlabs, the samples were analysed with the 4Litho code procedure. Samples were first fused with lithium metaborate/tetraborate and then subjected to acid digestion. Major elements and some trace elements were determined by inductively couple plasma-optical emission spectroscopy (ICP-OES), whereas the rest of the trace elements were determined by inductively coupled plasma-mass spectrometry (ICP-MS). At Acmelabs samples were analysed with the 4B code procedure. Major and minor elements were determined by ICP-OES, and trace elements (Ba, $\mathrm{Cs}, \mathrm{Ga}, \mathrm{Hf}, \mathrm{Nb}, \mathrm{Rb}, \mathrm{Sr}$, Ta, Th, U, V, Zr, Y and REEs) by ICP-MS. In both cases, fusion with lithium metaborate/tetraborate flux was conducted upon completion of rock powder dissolution. At INTEMIN, major oxides were determined by X-ray fluorescence after fusion with lithium tetraborate, whereas trace element determination was performed with the ICP-MS technique.

\section{Geochronology}

Sample T3 revealed an easily interpretable, consistent dataset (Table 1; Table S1 in the online Supplementary Material available at http://journals.cambridge.org/geo). The age spectrum is characterized by a general U-shape, with initial high values (step $1 \sim 419 \mathrm{Ma}$; Fig. 3a; Table S1 in the online Supplementary Material available at http://journals. cambridge.org/geo) that decrease to $\sim 76 \mathrm{Ma}$ with $\sim 10$ $90 \%$ of gas released, followed by an increase in the final phase of gas release. The total gas age of this sample is $87.7 \pm 0.3 \mathrm{Ma}$. Steps $7-11$ (58\% of the ${ }^{39} \mathrm{Ar}$ released) define a younger plateau age of $76.1 \pm 0.4 \mathrm{Ma}$ (Fig. 3a; Table 1). Steps $5-13$ (87\% of the ${ }^{39} \mathrm{Ar}$ released) define a valid isochron that yields an age of $68.6 \pm 0.6 \mathrm{Ma}$. The isochron gives an initial ${ }^{40} \mathrm{Ar} /{ }^{36} \mathrm{Ar}$ isotopic composition of $283 \pm 18$, which does not suggest that excess argon is present. However, the U-shaped age spectrum, and the younger isochron 
a

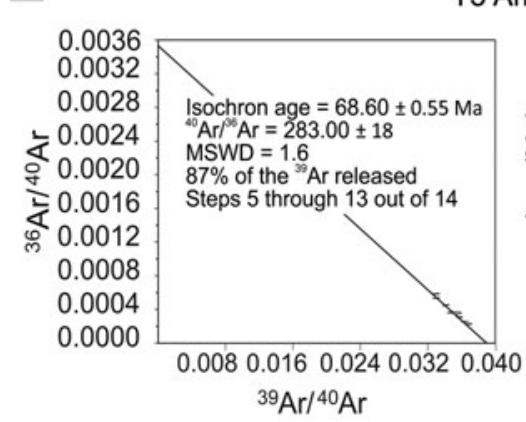

T3 Amphibole

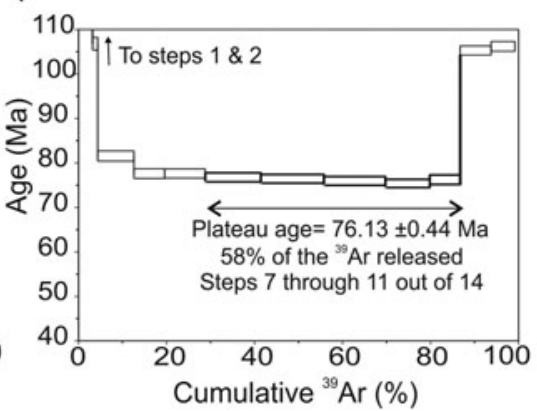

b

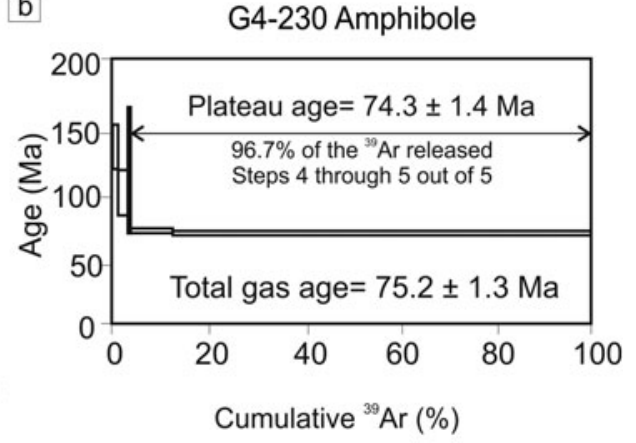

Figure 3. ${ }^{40} \mathrm{Ar}-{ }^{39} \mathrm{Ar}$ age spectrum and isochron obtained from single grains from the dacitic lavas at Gastre from sample (a) T3 and (b) G4-230.

age could suggest that excess argon is present. $\mathrm{Ca} / \mathrm{K}$ values and radiogenic yields are consistently high, indicating outgassing of a homogeneous, unaltered amphibole mineral separate (Table S1 in the online Supplementary Material available at http://journals.cambridge.org/geo). The plateau age is considered the most accurate and reliable age as it roughly coincides with the age of the other sample shown below (Table 1; Fig. 3a).

Sample G4-230 yielded a well-behaved age spectrum and a plateau age of $74.3 \pm 1.4 \mathrm{Ma}$ on two steps of high temperature that encompass $96.7 \%$ of the ${ }^{39} \mathrm{Ar}$ released (last two steps out of five; Fig. 3b; Table 1; Table S1 in the online Supplementary Material available at http://journals. cambridge.org/geo). On the inverse isochron plot, all points form a linear regression, characterized by an age value of $75.2 \pm 1.3 \mathrm{Ma}$, and a MSWD = 1.8 (Table 1; Fig. 3b). The three age values are broadly consistent, but the plateau age is considered as the most reliable one of this sample, as the $\mathrm{Ca} / \mathrm{K}$ ratio in the last two steps is consistently high (Table 1; Table S1 in the online Supplementary Material available at http://journals.cambridge.org/geo).

\section{Geochemistry}

The results obtained by the three laboratories broadly match (Table S2 in the online Supplementary Material available at http://journals.cambridge.org/geo). The analysed samples show 64.07-64.5\% $\mathrm{SiO}_{2}, 1.54-1.61 \% \mathrm{~K}_{2} \mathrm{O}, 4.03-5.05 \%$ $\mathrm{Na}_{2} \mathrm{O}$ and a $\mathrm{Mg}$ \# of between 66.08 and 57.18 (anhydrous base, loss on ignition (LOI) contents between 3.51 and 1.40; Table S2 in the online Supplementary Material available at http://journals.cambridge.org/geo). On the TAS diagram, rocks are classified as dacites, very close to andesites (Le Bas et al. 1986), and as ryodacites/dacites according to the Winchester \& Floyd (1977) diagram based on immobile elements.

Chondrite-normalized rare earth element (REE) patterns of the samples are enriched in light REEs and depleted in heavy REEs $\left((\mathrm{La} / \mathrm{Sm})_{\mathrm{N}}>2\right.$ and $(\mathrm{La} / \mathrm{Yb})_{\mathrm{N}}>10$; Table S2 in the online Supplementary Material available at http:// journals.cambridge.org/geo; Fig. 4a). Samples do not show negative Eu anomalies (Table S2 in the online Supplementary Material available at http://journals.cambridge.org/geo; Fig. 4a), suggesting an absence of plagioclase fractionation. Conversely, the middle and heavy REE slope denotes amphibole fractionation (Fig. 4a, b), suggesting that differentiation processes may have occurred at or near the base of the crust. On the other hand, chondrite-normalized heavy REE concentrations lower than 10 and $\mathrm{Sm} / \mathrm{Yb}$ ratios $>3.5$ are consistent with residual garnet in the source of these magmas (Table S2 in the online Supplementary Material available at http://journals.cambridge.org/geo). The Primor- dial Mantle normalized pattern of the samples bears enrichment in $\mathrm{Rb}, \mathrm{Sr}, \mathrm{K}, \mathrm{Ba}, \mathrm{Th}, \mathrm{U}, \mathrm{La}$ and $\mathrm{Ce}$, and depletion in $\mathrm{Nb}, \mathrm{Ta}, \mathrm{Ti}, \mathrm{Dy}, \mathrm{Y}, \mathrm{Yb}$ and Lu (Fig. 4b), showing a remarkable negative $\mathrm{Ta}-\mathrm{Nb}$ anomaly. Trace element ratios of $\mathrm{La} / \mathrm{Ta}>25, \mathrm{Ba} / \mathrm{Nb}>40, \mathrm{Ba} / \mathrm{Ta}>450, \mathrm{Ta} / \mathrm{Hf}>$ 0.15 and $\mathrm{La} / \mathrm{Nb}>1$ are typical of subduction environments (Table S2 in the online Supplementary Material available at http://journals.cambridge.org/geo).

\section{Discussion}

The new geochronological data reported in this work indicate the occurrence of volcanic activity during Late Cretaceous times in Gastre in Northern Patagonia. It should be noted that the recent find of a tuffaceous deposit within the Paso del Sapo Formation, $70 \mathrm{~km}$ southeast of Gastre, for which a maximum sedimentation age of $\sim 83 \mathrm{Ma}$ was inferred (U-Pb in zircons; Echaurren et al. 2016), provides another piece of evidence of volcanic activity during Late Cretaceous times in the region.

\section{6.a. Comparison between the Late Cretaceous and the Early to Middle Jurassic rocks in Gastre}

Until now, the Cretaceous volcanic rocks in Gastre had remained unnoticed, as their field and petrographic characteristics are very similar to those of the Early-Middle Jurassic andesites of the Lonco Trapial Formation. These rocks show higher total REE contents and higher levels of $\mathrm{Ba}, \mathrm{Rb}$, high-field-strength elements (HFSE) and light REEs than the Late Cretaceous dacites (Fig. 4a, b; pers. comm.). The Lonco Trapial volcanic rocks display higher $\mathrm{Ba} / \mathrm{Nb}$ and $\mathrm{Ba} / \mathrm{La}$ ratios (Fig. 5a, b), typical of subduction-related magmas (pers. comm.). However, some rocks from the Lonco Trapial Formation present $\mathrm{Ta} / \mathrm{Hf}$ ratios higher than 0.15 (pers. comm.), suggesting an intraplate geochemical affinity, whereas the $\mathrm{Ta} / \mathrm{Hf}$ ratios of the Late Cretaceous rocks are $<0.15$, and therefore compatible with arc-derived magmas (Fig. 5c).

Regarding the depth of the source, while the Early-Middle Jurassic rocks have $\mathrm{Sm} / \mathrm{Yb}$ ratios ranging from 2.5 to 5 , which are compatible with the presence of amphibole or garnet in the residual source (pers. comm. and Bouhier et al. 2017), $\mathrm{Sm} / \mathrm{Yb}$ ratios of $\sim 4$ in the Cretaceous samples point to the presence of residual garnet in the source. Chondritenormalized heavy REE concentrations of the Late Cretaceous rocks (as shown in Fig. 4a) also characterize their deeper source.

\section{6.b. Possible origin of the Late Cretaceous volcanism in Gastre}

A regional analysis of the location and geochemical features of the Cretaceous to Palaeogene magmatic rocks of Northern 

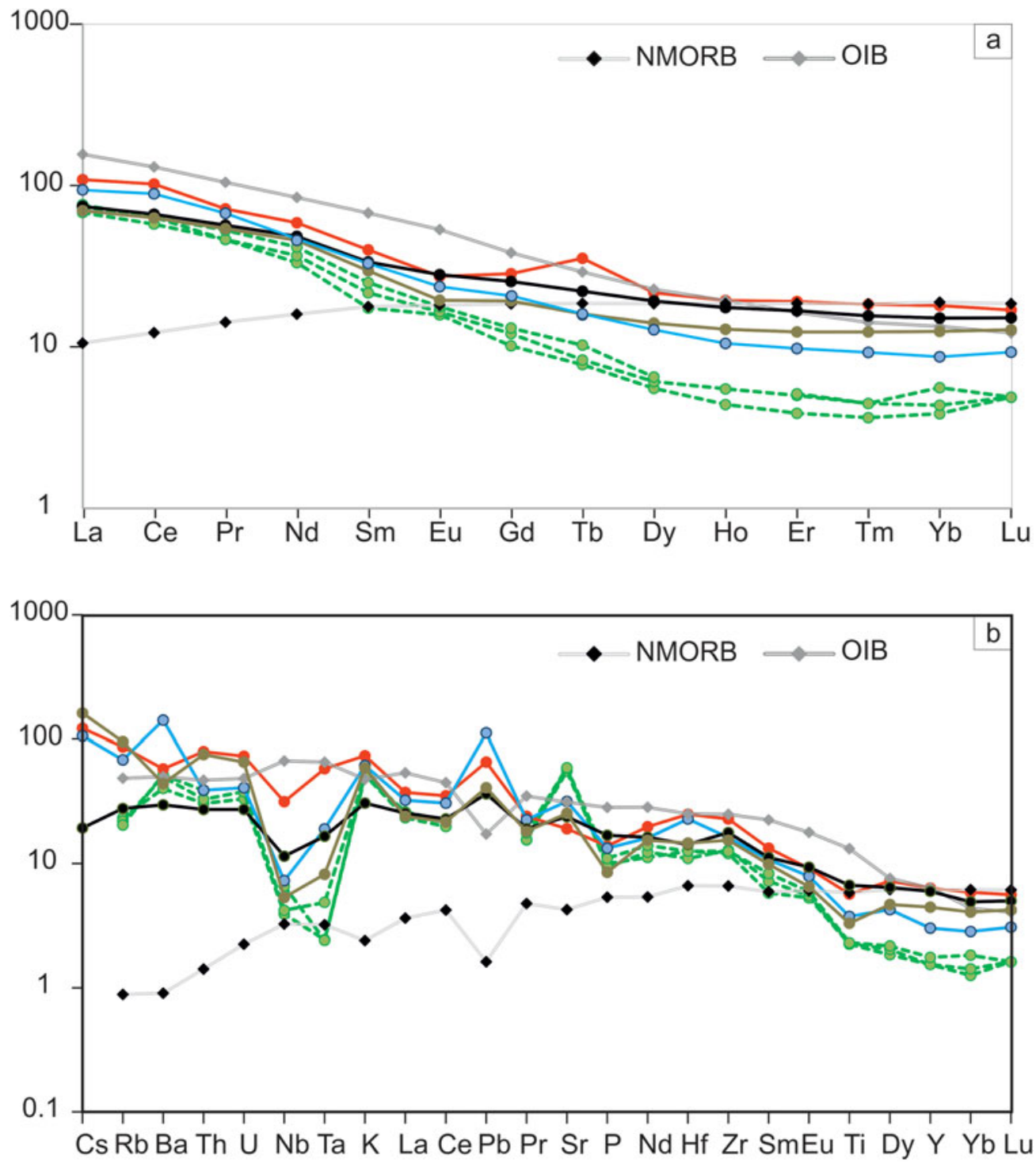

Paleocene-Eocene $\quad(\multimap$ Pilcaniyeu belt Late Cretaceous $\quad\left(\begin{array}{l}-\infty \cdot \cdot \text { T3 } \\ -\cdots-\cdot G 4-230 \\ -\infty-\cdot G 4-232\end{array}\right.$

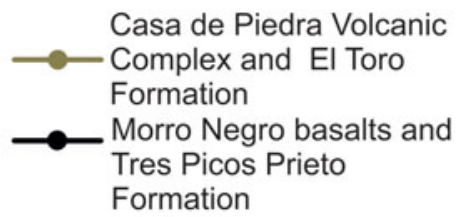

Early-Middle Jurassic Lonco Trapial Formation

Figure 4. (Colour online) Trace element composition of the dacitic lavas at Gastre. (a) REE pattern of the analysed rocks normalized to chondrite. (b) Primitive Mantle normalized multi-elemental plot. NMORB and OIB curves (Sun \& McDonough 1989) are shown for comparison, together with data from the Pilcaniyeu belt (Rapela et al. 1988; Aragón et al. 2011; Iannelli et al. 2017), the Casa de Piedra Volcanic Complex averaged with the El Toro Formation (data from Demant, Suárez \& De La Cruz, 2007), the Morro Negro basalts averaged with the Tres Picos Prieto Formation (data from Demant, Suárez \& De La Cruz, 2007 and Zaffarana, Lagorio \& Somoza, 2012) and Lonco Trapial Formation (unpub. data). Chondrite normalization is from McDonough \& Sun (1995) and Primitive Mantle normalization is from Sun \& McDonough (1989). All the comparisons were made with rocks whose $\mathrm{SiO}_{2}$ content is less than $70 \%$.

Patagonia is helpful to contextualize this newly found Late Cretaceous magmatism in Gastre. At least two hypotheses can be put forth with respect to its origin:

(a) This volcanism is equivalent to the Late Cretaceous volcanism in the Patagonia region (Tres Picos Prieto Formation), the already known northern outcrops of which are located at $\sim 44^{\circ} \mathrm{S}$ (Fig. 1). The porphyritic rocks from Gastre are coeval with those of the upper section of the Tres Picos Prieto Formation, according to the ages provided by Di Tommaso (unpub. Trabajo Final de Licenciatura, Univ. de Buenos Aires, 1978). The volcanic rocks from the Tres Picos Prieto Formation are, in turn, broadly correlated with the magmatic record of the same age in the Coihaique Alto region, in the Chilean Patagonian Andes (the Casa de Piedra Volcanic Complex, the El Toro Formation and the Morro Negro basalts, although the latter are slightly younger; Demant, Suárez \& De La Cruz, 2007; Fig. 1). 
a

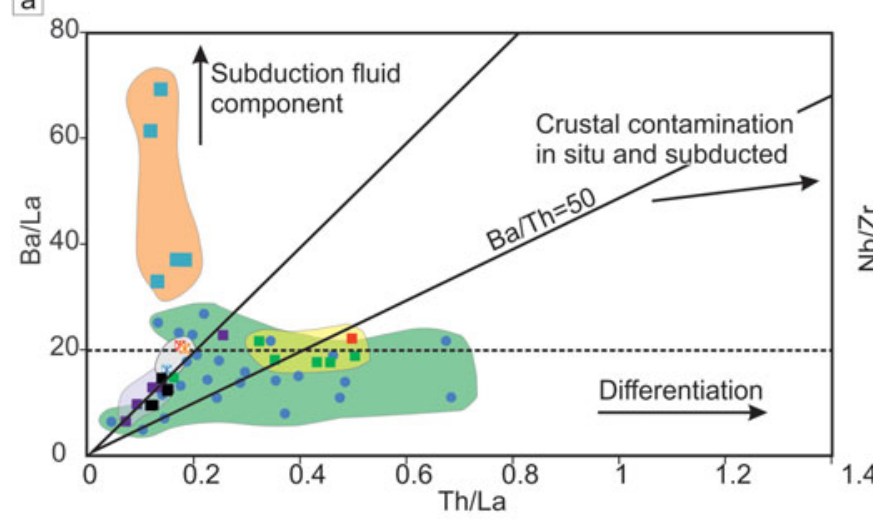

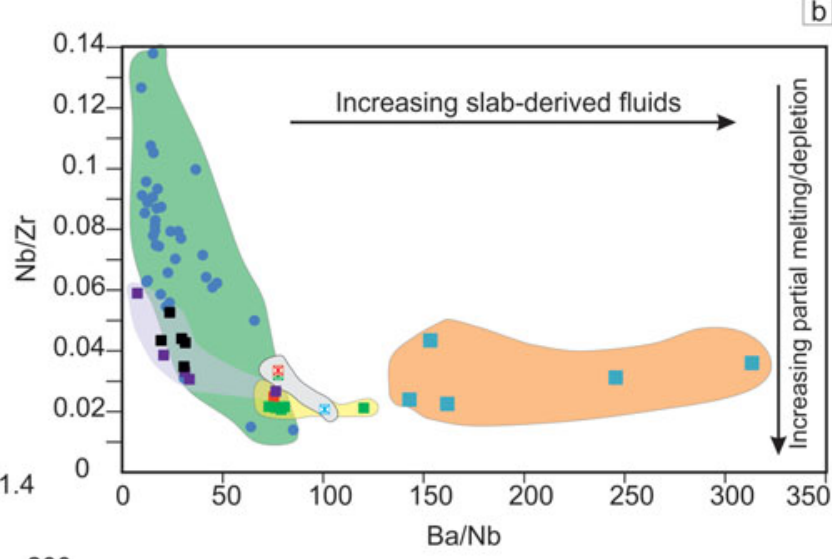

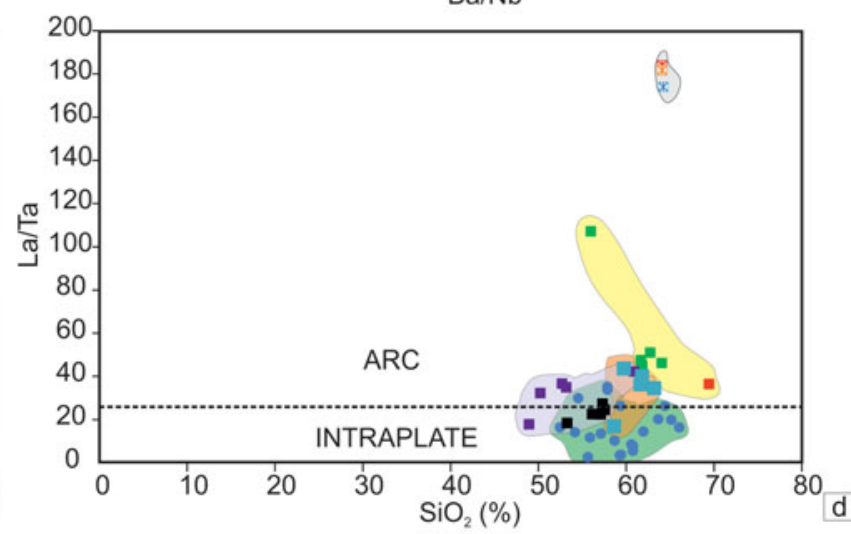

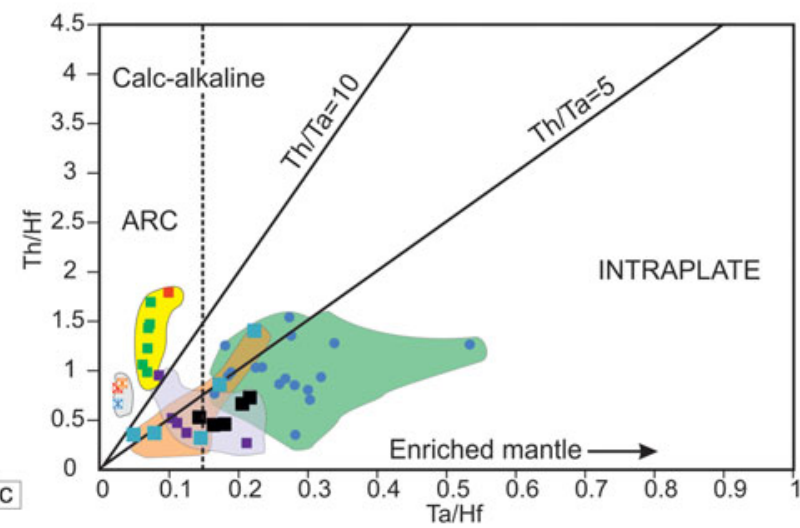

Pilcaniyeu belt

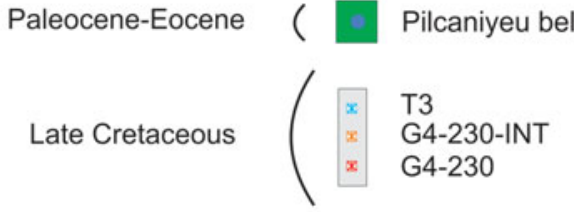

Casa de Piedra Volcanic Complex (Chile)

El Toro Formation (Chile)

Morro Negro basalts (Chile)

Tres Picos Prieto Formation

Early-Middle Jurassic

Lonco Trapial Formation

Figure 5. (Colour online) Trace element ratios of the dacitic lavas at Gastre showing their arc geochemical signature. (a) Plot of Ba/La v. Th/La. (b) plot of $\mathrm{Nb} / \mathrm{Zr}$ v. Ba/Nb. (c) Plot of Th/Hf vs. Ta/Hf. (d) Plot of $\mathrm{La} / \mathrm{Ta}$ vs. $\mathrm{SiO}_{2}$. Data from the Pilcaniyeu belt (Rapela et al. 1988; Aragón et al. 2011; Iannelli et al. 2017), Casa de Piedra Volcanic Complex (Demant, Suárez \& De La Cruz, 2007), El Toro Formation (Demant, Suárez \& De La Cruz, 2007), Morro Negro basalts (Demant, Suárez \& De La Cruz, 2007), Tres Picos Prieto Formation (Zaffarana, Lagorio \& Somoza, 2012) and Lonco Trapial Formation (unpub. data) are shown for comparison; the chosen rocks had $\mathrm{SiO}_{2}$ content less than $70 \%$.

(b) It may represent an early manifestation of the Palaeogene volcanism in the Chubut river area and in the Northern Patagonian Andes (Rapela et al. 1988; Aragón \& Mazzoni, 1997; Aragón et al. 2011; Iannelli et al. 2017).

The Late Cretaceous magmatic rocks bear a well-defined subduction signature, whereas the Palaeogene rocks present a distinctive intraplate geochemical signature (the Late Cretaceous magmas show more negative $\mathrm{Ta}$ and $\mathrm{Nb}$ anomalies, lower levels of $\mathrm{Hf}, \mathrm{Zr}$ and $\mathrm{La}$, higher $\mathrm{La} / \mathrm{Ta}, \mathrm{Th} / \mathrm{Hf}$ and $\mathrm{Ba} / \mathrm{Nb}$ ratios and lower $\mathrm{Ta} / \mathrm{Hf}$ ratios than Palaeogene magmas; see Figs 4a, b, 5a-d).

The Late Cretaceous rocks from Gastre display more distinct $\mathrm{Nb}-\mathrm{Ta}$ anomalies, lower levels of $\mathrm{Hf}, \mathrm{Zr}$ and $\mathrm{La}$, higher $\mathrm{La} / \mathrm{Ta}, \mathrm{Th} / \mathrm{Hf}$ and $\mathrm{Ba} / \mathrm{Nb}$ ratios as well as lower $\mathrm{Ta} / \mathrm{Hf}$ ratios than the Palaeogene samples (Figs $4 a, b, 5 a-d)$. It is noticeable that while the Late Cretaceous rocks bear a well-defined subduction signature, the Palaeogene rocks show a characteristic intraplate geochemical signature instead.

With regards to the Late Cretaceous volcanism, the rocks from Gastre show more geochemical similarities with those of the Casa de Piedra Volcanic Complex and the El Toro
Formation, as shown by the $\mathrm{La} / \mathrm{Ta}, \mathrm{Ta} / \mathrm{Hf}, \mathrm{Ba} / \mathrm{Nb}$ and $\mathrm{Ba} / \mathrm{La}$ ratios (Fig. 5). $\mathrm{La} / \mathrm{Ta}>25$ and $\mathrm{Ta} / \mathrm{Hf}<0.15$ point to the influence of slab-derived fluids in the mantle source of these magmas. In turn, the Late Cretaceous rocks from the Tres Picos Prieto Formation display distinctly lower ratios of $\mathrm{La} / \mathrm{Ta}$ (18-27) and of Ta/Hf (0.14-0.22), as well as $\mathrm{Ba} / \mathrm{La}<20$ and $\mathrm{Ba} / \mathrm{Nb}<40$ (Fig. 5), showing a geochemical signature transitional between arc and intraplate magmas (Zaffarana, Lagorio \& Somoza, 2012).

\section{6.c. Tectonic interpretation}

The calc-alkaline Late Cretaceous rocks from Gastre can be correlated with those from the Casa de Piedra Volcanic Complex and with those from the El Toro Formation in the Coihaique Alto region in Chile. It is worthy of mention that according to several studies concerning the Patagonian Batholith, there was a gap or decrease in its magmatic activity during Late Cretaceous times (Pankhurst et al. 1999; Suárez et al. 2010; Echaurren et al. 2016). The location 

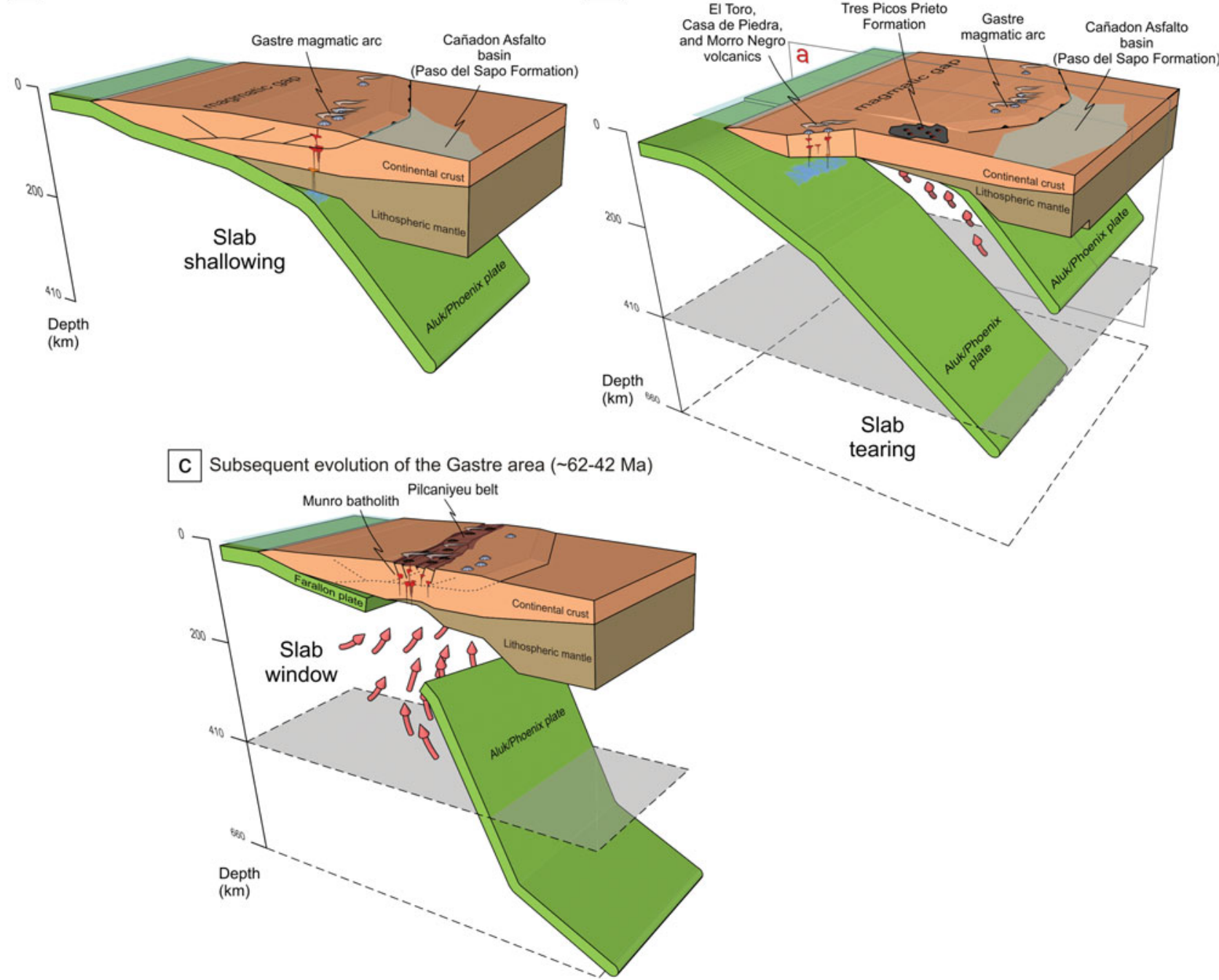

Figure 6. (Colour online) Schematic cartoons showing proposed tectonic processes and magmatic evolution for the study area. (a) Late Cretaceous slab shallowing related to the arc magmatism at the Gastre locality and related deformational belt and associated synorogenic basin. (b) Broad picture showing contemporaneous magmatism with a slab-tearing process allowing mantle flow sourcing the Tres Picos Prieto Formation. The age of $\sim 83$ Ma belongs to the tuffaceous intercalation in the Paso del Sapo Formation (Echaurren et al. 2016), whereas the age of $\sim 73$ Ma corresponds to the youngest age of the volcanites reported in this work (Table S2 in the online Supplementary Material available at http://journals.cambridge.org/geo). The ages of the Tres Picos Prieto Formation from Di Tommaso (unpub. Trabajo Final de Licenciatura, Univ. de Buenos Aires, 1978) are within this range. (c) Post-orogenic and extensional magmatism related to ridge subduction and slab window generation. The age of $\sim 60-42 \mathrm{Ma}$ of the Pilcaniyeu belt was taken from Rapela et al. (1988) and the age of $\sim 62 \mathrm{Ma}$ (within error) for the Munro Batholith was taken from Aragón et al. (2017).

of Gastre, about $250 \mathrm{~km}$ east of the present Southern Volcanic Zone of the Andes (Stern, 2004) and around $500 \mathrm{~km}$ east of the trench, suggests a likely migration of the volcanic arc front towards the east during Late Cretaceous times (Fig. 6a). An increase in the depth of the source, suggested by the garnet-bearing source of the Gastre dacites, correlates well with crustal thickening. According to Karlstrom, Lee \& Manga (2014), crustal thickening could drive arc front migration while truncating the melt column at depth.

In addition, several authors have proposed the existence of a Late Cretaceous compressive deformation in Northern Patagonia (Allard, Giacosa \& Paredes, 2011; Folguera \& Ramos, 2011; García Morabito \& Ramos, 2012; Gianni et al. 2015; Echaurren et al. 2016). They argued that an eastward migration of the arc magmatism could have been produced by a slab-shallowing process occurring in the central and Northern Patagonian Andes, a process probably associated with a general compressive deformation regime during Late
Cretaceous times (García Morabito \& Ramos, 2012; Spagnuolo et al. 2012; Gianni et al. 2015; Echaurren et al. 2016; Fig. 6a). Furthermore, thermochronological studies have revealed the existence of Late Cretaceous-Palaeogene exhumation ages in the Gastre region (Savignano et al. 2016), which can be associated with a compressive deformation stage, that was later followed by a post-orogenic collapse stage. Further southwest, by contrast, at the latitude of the El Toro Formation and the Casa de Piedra Volcanic Complex, a normal subduction regime must have been re-established (see regional tectonic framework depicted in Fig. 6b).

It is noteworthy that between both zones, near the locality of José de San Martín, the lavas of the Tres Picos Prieto Formation show an intermediate geochemical signature between intraplate and subduction magmas. The Late Cretaceous volcanism of the Tres Picos Prieto Formation could have been due to slab rollback leading to an effective trench retreat and its associated lithosphere extension, 
occurring soon after the Early Cretaceous contractional event (95-90 Ma; Somoza \& Zaffarana, 2008), as is suggested by Zaffarana, Lagorio \& Somoza (2012). In the latter scenario, while the trench retreated to the west, a slab-tearing process in the Aluk/Phoenix oceanic plate could have created the conditions for the extrusion of the Tres Picos Prieto basalts (Fig. 6b). Slab tearing would have occurred owing to a change in the subduction angle, passing from flat at the latitude of Gastre, to normal further south, at the latitude of the Coihaique Alto region. Slab tearing allows the contamination of the subduction magmas with asthenospheric magmas derived from lateral asthenospheric flow. Lateral asthenospheric flow is a common feature along a wide subduction system like the Andes (Schellart et al. 2007). This could have been the cause of the transitional geochemical character of the lavas of the Tres Picos Prieto Formation (Fig. 6b).

Late Cretaceous to recent mafic volcanism in Patagonia developed above a rapidly shearing asthenosphere, and therefore shear-driven upwelling (Conrad et al. 2010) seems to be a geodynamic process capable of contributing to the genesis of most of the back-arc to intraplate lavas in Patagonia, such as those of the Tres Picos Prieto Formation (Zaffarana, Lagorio \& Somoza, 2012). However, slab tearing particularly seems to be more suitable for triggering the extrusion of the Tres Picos Prieto lavas, considering the scenario depicted in Figure 6b. Figure 6 also emphasizes that different tectonic conditions coexisted along the continental margin during Late Cretaceous times.

It is worth highlighting that the timing of the collision of the Farallon-Aluk ridge with the continental margin is still under discussion and varies with the latitude, and while some authors relate it to Paleocene-Eocene times (Cande \& Leslie, 1986; Ramos \& Kay, 1992; Seton et al. 2012), further south, in the Coihaique Alto region in Chile, it is inferred that it occurred earlier, during Late Cretaceous-Palaeogene times (Espinoza et al. 2005; Demant, Suárez \& De La Cruz, 2007). The origin of the Tres Picos Prieto lavas was also ascribed to slab melting due to active Farallon-Aluk ridge subduction and slab window generation (Gianni et al. 2015; Echaurren et al. 2016). However, there is no slab melting signature in the Tres Picos Prieto basalts, as suggested by their relatively low $\mathrm{Mg}$ content and their high $\mathrm{Sr} / \mathrm{Y}$ ratios, which plot away from the adakitic field (Zaffarana, Lagorio \& Somoza, 2012).

In a similar way, at the latitude of Gastre, the passage of the Farallon-Aluk ridge during Palaeogene times was also argued by Aragón et al. (2017) to explain the widespread extensional tectonic regime that prevailed during the effusion of the intraplate-derived magmas of the Pilcaniyeu Belt (60 to $42 \mathrm{Ma}$; Rapela et al. 1988; Aragón et al. 2013) and the intrusion of the granitic magmas of the post-orogenic Munro Batholith $(\sim 62 \mathrm{Ma})$, as illustrated in Figure 6c.

\section{Conclusion}

The newly found Late Cretaceous dacites ( 74-76 Ma) in Gastre, Northern Patagonia bear a calc-alkaline, arc-like geochemical signature and a deep, garnet-bearing source. Given that there was a magmatic decrease or gap in the arc activity during Late Cretaceous times at these latitudes, an eastward migration of the magmatic front is proposed in this period. Further south, the activity of the magmatic front must be inferred from the coeval, arc-derived magmas of the El Toro Formation and the Casa de Piedra Volcanic Complex, which are located close to the prior arc axis.

The eastward expansion of the arc at the latitude of Gastre correlates well with a regional compressive deformation event, supported by independent structural and thermo- chronological studies. The compressive deformation and the eastward arc migration are probably associated with a slabshallowing process.

In a complementary way, the Late Cretaceous volcanism of the Tres Picos Prieto Formation, which bears transitional features between intraplate and subduction-related magmas, could have been triggered by a slab-tearing process in the Aluk-Phoenix oceanic plate due to the change in the subduction angle (from flat at the latitude of Gastre to normal at $\sim 45^{\circ} \mathrm{S}$ ), while the trench was retreating to the west. Different geochemical features of coeval volcanic rocks suggest that different tectonic conditions existed along the continental margin during Late Cretaceous times.

Acknowledgements. This work was financed by the Project PIP CONICET 112-200901-00766 and Project PICT 20141394. Gabriela Massaferro and Felipe Espinoza are thanked for reviewing this manuscript. Special thanks are given to Maria Helena Hollanda for helping with the geochemical analysis of one of the samples at Acmelabs, and to Romina Sulla for revising the English text.

\section{Supplementary material}

To view supplementary material for this article, please visit https://doi.org/10.1017/S0016756818000432

\section{References}

Allard, J. O., Giacosa, R. \& Paredes, J. M. 2011. Relaciones estratigráficas entre la Formación los Adobes (Cretácico inferior) y su sustrato Jurásico: implicancias en la evolución tectónica de la cuenca de Cañadón Asfalto, Chubut, Argentina. In XVIII Congreso Geológico Argentino (eds H. A. Leanza, M. Franchini, A. Impiccini, G. Pettinari, M. Sigismondi, J. Pons \& M. Tunik), pp. 988-9. Neuquén.

Aragón, E., Castro, A., Giacosa, R., Rodríguez, C., D’Eramo, F., Pinotti, L., Díaz-Alvarado, J., Aguilera, Y., Cavarozzi, C., Demartis, M., Hernando, I. R., Fuentes, T. \& Ribot, A. 2017. El Batolito Munro: magmatismo post-orogénico paleoceno en el rift de los Patagónides: Patagonia Extrandina. In XX Congreso Geológico Argentino, Simposio 12 (eds L. Ibañez, P. Grosse \& M. Báez), pp. 13-18. Asociación Geológica Argentina.

Aragón, E., D’Eramo, F. D., Castro, A., Pinotti, L., Brunelli, D., Rabbia, O., Rivalenti, G., Varela, R., Spakman, W., Demartis, M., Cavarozzi, C. E., Aguilera, Y. E., Mazzucchelli, M. \& Ribot, A. 2011. Tectono-magmatic response to major convergence changes in the North Patagonian suprasubduction system; the Paleogene subduction - transcurrent plate margin transition. Tectonophysics 509, 218-37.

Aragón, E. \& Mazzoni, M. 1997. Geología y estratigrafía del complejo volcánico piroclástico del río Chubut medio (Eoceno), Chubut. Argentina. Revista de la Asociación Geológica Argentina 52, 243-56.

Aragón, E., Pinotti, L., Eramo, F. D., Castro, A., Rabbia, O., Coniglio, J., Demartis, M., Hernando, I., Cavarozzi, C. E. \& Aguilera, Y. E. 2013. The Farallon-Aluk ridge collision with South America: implications for the geochemical changes of slab window magmas from fore- to back-arc. Geoscience Frontiers 4, 377-88.

Bouhier, V. E., Franchini, M. B., Caffe, P. J., Maydagán, L., Rapela, C. W. \& PaOlini, M. 2017. Petrogenesis of 
volcanic rocks that host the world-class $\mathrm{Ag}-\mathrm{Pb}$ Navidad District, North Patagonian Massif: comparison with the Jurassic Chon Aike Volcanic Province of Patagonia, Argentina. Journal of Volcanology and Geothermal Research 338, 101-20.

Cande, S. \& Leslie, R. 1986. Late Cenozoic tectonics of the southern Chile Trench. Journal of Geophysical Research 91 (B1), 471-96.

Castro, A., Moreno-Ventas, I., Fernández, C., Vujovich, G., Gallastegui, G., Heredia, N., Martino, R. D., Becchio, R., Corretgé, L. G., DíaZAlvarado, J., Such, P., García-Arias, M., \& Liu, D. 2011. Petrology and SHRIMP U-Pb zircon geochronology of Cordilleran granitoids of the Bariloche area, Argentina. Journal of South American Earth Sciences 32, 508-30.

Conrad, C. P., Wu, B., Smith, E. I., Bianco, T. A. \& TibBetTs, A. 2010. Shear-driven upwelling induced by lateral viscosity variations and asthenospheric shear: a mechanism for intraplate volcanism. Physics of the Earth and Planetary Interior 178, 162-75.

Demant, A., Suárez, M. \& De La Cruz, R. 2007. Geochronology and petrochemistry of Late Cretaceous- (?) Paleogene volcanic sequences from the eastern central Patagonian Cordillera $\left(45^{\circ}-45^{\circ} 40^{\prime} \mathrm{S}\right)$. Revista Geológica de Chile 34, 3-21.

Echaurren, A., Folguera, A., Gianni, G., Orts, D., Tassara, A., Encinas, A., Giménez, M. \& Valencia, V. 2016. Tectonic evolution of the North Patagonian Andes $\left(41^{\circ}-44^{\circ} \mathrm{S}\right)$ through recognition of syntectonic strata. Tectonophysics 677, 99-114.

Echaurren, A., Oliveros, V., Folguera, A., Ibarra, F., Creixell, C. \& Lucassen, F. 2017. Early Andean tectonomagmatic stages in north Patagonia: insights from field and geochemical data. Journal of the Geological Society, London 174, 405-21.

Espinoza, F., Morata, D., Polvé, M., Bellen, H., Cotten, J., De La Cruz, R. \& Guivel, C. 2005. Petrogenesis in Meseta Chile Chico, southern Patagonia, Chile: evidence for the participation of two slab windows. Lithos 85, 315-43.

Folguera, A. \& Ramos, V. A. 2011. Repeated eastward shifts of arc magmatism in the Southern Andes: a revision to the long-term pattern of Andean uplift and magmatism. Journal of South American Earth Sciences 32, 531-46.

Franchi, M. R. \& Page, R. F. N. 1980. Los basaltos cretácicos y la evolución magmática del Chubut occidental. Revista de la Asociación Geológica Argentina 35 (2), 208-29.

García Morabito, E. \& Ramos, V. A. 2012. Andean evolution of the Aluminé fold and thrust belt, Northern Patagonian Andes $\left(38^{\circ} 30^{\prime}-40^{\circ} 30^{\prime} \mathrm{S}\right)$. Journal of South American Earth Sciences 38, 13-30.

Gianni, G., Navarrete, C., Orts, D., Tobal, J., Folguera, A. \& GimÉneZ, M. 2015. Patagonian broken foreland and related synorogenic rifting: the origin of the Chubut Group Basin. Tectonophysics 649, 81-99.

Iannelli, S. B., Litvak, V. D., Fernández PaZ, L., Folguera, A., Ramos, M. E. \& Ramos, V. A. 2017. Evolution of Eocene to Oligocene arc-related volcanism in the North Patagonian Andes $\left(39-41^{\circ} \mathrm{S}\right)$, prior to the break-up of the Farallon plate. Tectonophysics 696697, 70-87.

Karlstrom, L., Lee, C. T. A. \& Manga, M. 2014. The role of magmatically driven lithospheric thickening on arc front migration. Geochemistry, Geophysics, Geosystems, 15, 2655-75.
Le Bas， M. J., Lemaître， R. W.，Streckeisen， A. \& ZANETTIN, B. 1986. A chemical classification of volcanic rocks based on the total alkali-silica diagram. Journal of Petrology 27, 745-50.

McDonough, W. F. \& Sun, S. S. 1995. The composition of the Earth. Chemical Geology 120, 223-53.

Page, R. \& PAGE, S. 1993. Petrología y significado tectónico del Jurásico volcánico del Chubut Central. Revista de la Asociacion Geologica Argentina 48, 41-58.

Pankhurst, R. J., Weaver, S. D., Hervé, F. \& Larrondo, P. 1999. Mesozoic-Cenozoic evolution of the North Patagonian batholith in Aysen, southern Chile. Journal of the Geological Society, London 156, 673-94.

Ramos, V. A. \& KAY, S. M. 1992. Southern Patagonian plateau basalts and deformation: backarc testimony of ridge collisions. Tectonophysics 205, 261-82.

Rapela, C. W., Spalletti, L. A., Merodio, J. C. \& Aragón, E. 1988. Temporal evolution and spatial variation of early Tertiary volcanism in the Patagonian Andes $\left(40^{\circ} \mathrm{S}-42^{\circ} 30^{\prime} \mathrm{S}\right)$. Journal of South American Earth Sciences $\mathbf{1}, 75-88$.

Rolando, A. P., Hartmann, L. A., Santos, J. O. S., FERNANDEZ, R. R. \& ETCHEVERRY, R. O. 2002. SHRIMP zircon $\mathrm{U} \pm \mathrm{Pb}$ evidence for extended Mesozoic magmatism in the Patagonian Batholith and assimilation of Archean crustal components. Journal of South American Earth Sciences 15, 267-83.

Savignano, E., Mazzoli, S., Arce, M., Franchini, M., Gautheron, C., Paolini, M. \& Zattin, M. 2016. (Un)coupled thrust belt-foreland deformation in the northern Patagonian Andes: new insights from the Esquel-Gastre sector $\left(41^{\circ} 30^{\prime}-43^{\circ} \mathrm{S}\right)$. Tectonics 35, 2636-56.

Schellart, W. P., Freeman, J., Stegman, D. R., Moresi, L. \& MAY, D. 2007. Evolution and diversity of subduction zones controlled by slab width. Nature 446, 308-11.

Seton, M., Müller, R. D., Zahirovic, S., Gaina, C., Torsvik, T., Shephard, G., Talsma, A., Gurnis, M, Turner, M, Maus, S. \& Chandler, M. 2012. Global continental and ocean basin reconstructions since $200 \mathrm{Ma}$. Earth-Science Reviews 113, 212-70.

Somoza, R. \& ZafFarana, C. B. 2008. Mid-Cretaceous polar standstill of South America, motion of the Atlantic hotspots and the birth of the Andean cordillera. Earth and Planetary Science Letters 271, 267-77.

Spagnuolo, M. G., Folguera, A., Litvak, V., Vera, E. A. R. \& Ramos, V. A. 2012. Late Cretaceous arc rocks in the Andean retroarc region at $36.5^{\circ} \mathrm{S}$ : evidence supporting a Late Cretaceous slab shallowing. Journal of South American Earth Sciences 38, 44-56.

Stern, C. R. 2004. Active Andean volcanism: its geologic and tectonic setting. Revista Geológica de Chile 31, 161-206.

Suárez, M., De La Cruz, R., Bell, M. \& Demant, A. 2010. Cretaceous slab segmentation in southwestern Gondwana. Geological Magazine 147, 193-205.

Sun, S. S. \& McDonough, W. F. 1989. Chemical and isotopic systematics of oceanic basalts: implications for mantle composition and processes. In Magmatism in the Ocean Basins (eds A. D. Saunders \& M. J. Norry), pp. 313-45. Geological Society of London, Special Publication no. 42.

Whitney, D. L. \& Evans, B. W. 2010. Abbreviations for names of rock-forming minerals. American Mineralogist 95: 185-7.

Winchester, J. A. \& Floyd, P. A. 1977. Geochemical discrimination of different magma series and their 
differentiation products using immobile elements. Chemical Geology 20, 325-43.

Zaffarana, C. B., Lagorio, S. L. \& Somoza, R. 2012. Paleomagnetism and geochemistry from the Upper Cretaceous Tres Picos Prieto locality $\left(43^{\circ} \mathrm{S}\right)$, Patagonian Plateau Basalts. Andean Geology 39, 53-66.
Zaffarana, C. B. \& Somoza, R. 2012. Paleomagnetism and ${ }^{40} \mathrm{Ar}-{ }^{39} \mathrm{Ar}$ dating from Lower Jurassic rocks in Gastre, central Patagonia: further data to explore tectonomagmatic events associated to Gondwana breakup Journal of the Geological Society, London 169, $371-9$. 